http://jmscr.igmpublication.org/home/

ISSN (e)-2347-176x ISSN (p) 2455-0450

crossref DOI: https://dx.doi.org/10.18535/jmscr/v8i7.64

Journal Of Medical Science And Clinical Research

\title{
Prevalence of Anemia and Socio demographic factors associated with Anemia among Barwar tribe of Gonda district, Uttar Pradesh
}

\author{
Author \\ Biswajit Mahapatra ${ }^{1,2}$ \\ ${ }^{1}$ Senior Research Fellow, Anthropological Survey ofIndia, Head Office, 27, Jawaharlal Nehru Road, \\ Kolkata-700016, West Bengal, India \\ ${ }^{2} \mathrm{Ph} . \mathrm{D}$ Research Scholar, Department of Anthropology, Vidyasagar University, Midnapore-721102, \\ West Bengal, India \\ *Correspondence Author \\ Biswajit Mahapatra
}

Anthropological Survey of India, Head Office, 27, Jawaharlal Nehru Road, Kolkata-700016,

West Bengal, India

\begin{abstract}
Background: Anemia is one of the most widespread nutritional deficiency diseases and it affects all age groups and both sexes in most states of India. The aims and objectives of this study are to assess the prevalence of anemia among the Barwar community and find out any relationship between their sociodemographic factors with prevalence of anemia.

Materials and Methods: This was a population-based cross-sectional study conducted in a Denotified tribe (Barwar) of Gonda district, Uttar Pradesh among the age group from 20-59 years. Total 315 samples were collected and participants were selected by simple random sampling. All statistical analysis was done using SPSS software version 16.Digital hemoglobinometer was used to assess the Haemoglobin level and the World Health Organization recommended cutoff was used to diagnose and categorize anemia. The $\chi^{2}$ test and Pearson correlation was used to test the degree of significance.

Results: Overall prevalence of anemia was found to be $72.1 \%$ (61.7\% in males and $80.5 \%$ in females). Chi-square statistics shows significant association $(p<0.05)$ of anemia is with monthly family income, marital status, sanitation facilities, Gender and socioeconomic status. However, education and age trends were not significantly associated with anaemia. There is a significant association was found in gender with all socio demographic variables and anemia, except sanitation. Pearson's Correlation coefficient $(r)$ between hemoglobin and all socioeconomic and demographic factors were statistically significant $(p<0.05)$.
\end{abstract}

Conclusion: High prevalence of anemia among studied people indicates anemia to be a major public health problem in the Barwar community.

Keywords: Anemia, Denotified tribe, socioeconomic and demographic factors.

\section{Introduction}

Anaemia is an indicator of both poor nutrition and poor health. Hemoglobin concentration is the most reliable indicator of anaemia at the population level. ${ }^{24}$ Both nutritional and non-nutritional factors may cause anemia. The most common nutritional cause is iron deficiency. Iron deficiency anemia (IDA) results from a combination of several 
factors: (1) inadequate iron intake and/or low dietary availability; (2) high physiologic demands in early childhood and pregnancy, and periods of rapid growth such as adolescence; (3) chronic iron losses from parasitic infections such as hookworm and schistomiasis; and (4) deficiencies of vitamin B12, folic acid, and vitamin A. ${ }^{1,2}$ Studies have shown that with increase in house hold income the trend of anaemia decreases. ${ }^{9}$ Low socioeconomic status is an important risk factor for developing anaemia. ${ }^{10}$ Prevalence of anaemia is an indicator of poor nutrition and health. It has potential to negatively affect the social and economic development of Nation. ${ }^{11}$

As per National Family Health Survey-4 (NFHS4) in Uttar Pradesh, prevalence of anaemia among women and men were $52.4 \%$ and $23.7 \%$ respectively. ${ }^{3}$ High prevalence of anemia represents a poor nutrition status and reduced health of a population. ${ }^{4,5}$ Iron deficiencies is influenced by various host factors including age, sex and physiological, pathological, dietary and socioeconomic conditions. ${ }^{4}$ In India, supplementation of only iron and folic acid is inadequate to prevent or correct anaemia among adolescents (NFHS-4). ${ }^{25}$

Barwar is a denotified tribe listed "Idate Commission Report- 2017 (National Commission for Denotified, Nomadic and Semi- Nomadic Tribes), List- 1A and also, they enlisted schedule caste of the Uttar Pradesh list. The present study was undertaken in adult male and female' of Gonda district, Uttar Pradesh. Total eleven different places/ purwa/ villages are studied of Gonda district, Uttar Pradesh. According to 2011 census report of other three districts found in Barwar people. These are- I. Kheri district (total population is 14,196. Male- 7547 and female6649). II. Maharaj Ganj district (total population is 2957, male-1566 and female- 1391). III. Jhansi district (total population is 1814. Male- 990 and female- 824). ${ }^{14}$ They are speaking to Hindi dialect. Their main occupation is agriculture and daily wage labourer, some criminal records are also found. Hence, the present study was undertaken to determine the prevalence of anemia in relation to socio demographic factors. Thus, present study was undertaken to assess the prevalence of anemia among the Barwar community, and to find out any relationship between their socioeconomic status and demographic factors with prevalence of anemia.

\section{Materials and Methods}

A community based cross sectional study was carried out among Denotified tribe (Barwar) in eleven place/ purwa of Gonda district, Uttar Pradesh. A predesigned pretested and structural schedule questionnaire was used for the data collection. Data collection was done through personal interview of study subjects by trained investigator. Data were collected from September 2019 to October 2019. Sample is selected through random sampling. In the fieldwork, socio economic and demographic factors, Health, Hygiene and Hemoglobin related data were collected from 315 (141 males and 174 females) individuals of Barwar community. All sample (termed the reference sample) were interviewed and examined the all-males and females were taken among 20- 59 years old, subjects were classified into four groups, that is Group I:- 20-29 years, Group II:- 30- 39, Group III:- 40- 49, Group IV:-50- 59 years and the sex wise distributions among males and females in each age groups. The socioeconomic status is assessed by modified Kuppuswamy socioeconomic classification scale. ${ }^{13}$ Formal ethical approval was obtained from Anthropological Survey of India, 27, Jawaharlal Nehru Road, Head Office, Kolkata-700016, West Bengal, India, under the project of Ministry of Culture, Government of India.

Digital hemoglobinometer used for determine the hemoglobin level. The World Health Organization recommended cutoff for hemoglobin level was used to diagnose and categorize anemia. For males, cutoff for the diagnosis of anemia was <13 $\mathrm{g} / \mathrm{dl}$; categorization of anemia among males was done using the following cutoffs: $11-12.9 \mathrm{~g} / \mathrm{dl}$ (mild), 8-10.9 $\mathrm{g} / \mathrm{dl}$ (moderate), and $<8 \mathrm{~g} / \mathrm{dl}$ 
(severe). For females, cutoff for the diagnosis of anemia was $<12 \mathrm{~g} / \mathrm{dl}$; categorization of anemia among females was done using the following cutoffs: 11-11.9 g/dl (mild), 8-10.9 g/dl (moderate), and $<8 \mathrm{~g} / \mathrm{dl}$ (severe). ${ }^{12}$

We followed the World Health Organization (WHO, 2001) classification for assessing the public health problem by percentage prevalence ranges of this anemic indicator among Barwar people. The classification is categorized as table $1{ }^{4}$

\section{Statistical Analysis}

After collecting information and taking measurements, data was tabulated and analysed in Statistical Packages of Social Science (SPSS, version 16.0). The data was analysed for various aspects in terms of frequencies, percentages and means. Mean hemoglobin level and prevalence of anemia was calculated among different socio economic and demographic categories. Independent Sample $\mathrm{t}$ test was used to test for significant sex differences in mean hemoglobin. One-Way ANOVA (F test) was performed to observe significant categories differences in mean hemoglobin. Chi-square test $\left(\chi^{2}\right)$ used for categorical variables. The $\chi^{2}$ was used to study the association between the groups. Pearson's Correlation matrix was utilized to investigate the relation between anemia and hemoglobin with socio demographic variables.

\section{Results}

A total of 315people had participated in the study, of which $44.76 \%$ were male and $55.24 \%$ female subjects. Age-wise distribution showed that the prevalence of anemia in both sexes. The prevalence of anemia in male are $61.7 \%$ and females are $80.5 \%$. Age wise prevalence of anemia was not statistically significant in male but females are significant association $(\mathrm{p}<0.05)$ show in table 2.Table 3 show that socio demographic variables wise prevalence of anemia. $35.9 \%$ people are illiterate and $74.3 \%$ people monthly family income $<5000$ rupee. According to modified "Kuppuswamy socio- economic status scale" majority of the study subjects belonged to lower $(38.1 \%)$ and upper lower $(52.0 \%)$ class followed by lower middle $(7.0 \%)$ and upper middle $(2.9 \%)$. No people belonged to upper class. Prevalence of anemia is also high in low educated people, low income and lower socio-economic class. Table No 4 shows that socio demographic profile wise mean hemoglobin level of studied sample. The mean hemoglobin level of all the participants was $11.55 \pm 1.91 \mathrm{~g} / \mathrm{dl}$. Significant sex differences in mean hemoglobin were found in all socio-economic class except upper middle. Sex wise group differences are also found in most categories. Table No 5 represent the association of gender with socio demographic factors and anemia. Gender wise significant association found with the all socio demographic variables like education $(p<0.001)$, monthly family income $(\mathrm{p}<.01)$, marital status $(\mathrm{p}<.001)$, socio-economic status $(\mathrm{p}<.001)$, age category $(\mathrm{p}<.001)$ and anemic prevalence $(\mathrm{p}<.001)$. Only sanitation is not found significant association. Table No6 shows that association of anemia with socio demographic factors. Significant association of anaemia was found with the monthly family income $(p<.05)$, marital status $(p<.05)$, sanitation $(p<.01)$, socioeconomic status $(p<.05)$, and gender $(p<.001)$. Education and age category are not found significant association. Table No 7shows that Pearson's Correlation coefficient (r) between hemoglobin and anemia with socio demographic variables. All socio demographic parameters are statistically significant correlation found with anemia.

According to World Health Organization (WHO, 2001) classification for assessing the public health problem, the overall age and sex combined rate of anemia were severe condition among the studied community. Highest rates of anemia were observed at age group (20- 29 years) among females $(91.4 \%)$ and males $(74.2 \%)$ at age group 50-59 years. 
Table No: 1. Classification of anaemia as a problem of public health significance (WHO, 2001)

\begin{tabular}{|l|c|}
\hline Prevalence of anemia (\%) & Category of public health significance \\
\hline$\leq 4.9$ & No public health problem \\
\hline $5.0-19.9$ & Mild public health problem \\
\hline $20.0-39.9$ & Moderate public health problem \\
\hline$\geq 40.0$ & Severe public health problem \\
\hline
\end{tabular}

Table No: 2. Age wise prevalence of Anemia in male and female

\begin{tabular}{|c|c|c|c|c|c|c|}
\hline Age category & \multicolumn{3}{|c|}{ Male } & \multicolumn{3}{c|}{ Female } \\
\cline { 2 - 7 } & $\mathrm{n}$ & Anemic & Non anemic & $\mathrm{n}$ & Anemic & Non anemic \\
\hline $20-29$ & 55 & $27(49.1 \%)$ & $28(50.9 \%)$ & 35 & $32(91.4 \%)$ & $3(8.6 \%)$ \\
\hline $30-39$ & 22 & $14(63.6 \%)$ & $8(36.4 \%)$ & 53 & $38(71.7 \%)$ & $15(28.3 \%)$ \\
\hline $40-49$ & 33 & $23(69.7 \%)$ & $10(30.3 \%)$ & 53 & $40(75.5 \%)$ & $13(24.5 \%)$ \\
\hline $50-59$ & 31 & $23(74.2 \%)$ & $8(25.8 \%)$ & 33 & $30(90.9 \%)$ & $3(9.1 \%)$ \\
\hline Age combined & 141 & $87(61.7 \%)$ & $54(38.3 \%)$ & 174 & $140(80.5 \%)$ & $34(19.5 \%)$ \\
\hline & \multicolumn{3}{|c|}{$\chi^{2}=6.68^{\mathrm{NS}} ; \mathrm{df}=3 ; \mathrm{p}$ value $=.083$} & \multicolumn{3}{c|}{$\chi^{2}=8.40^{*} ; \mathrm{df}=3 ; \mathrm{p}$ value $=.038$} \\
\hline
\end{tabular}

Level of significance $*=p<0.05, \mathrm{~N}$. S $=$ Not significant

Table No: 3. Socio demographic profile wise prevalence of anemia of study participants

\begin{tabular}{|c|c|c|c|c|c|c|}
\hline \multirow{2}{*}{$\begin{array}{l}\text { Socio demographic } \\
\text { parameters }\end{array}$} & \multirow{2}{*}{$\begin{array}{c}\mathrm{N} \\
\mathrm{n}=315(\%)\end{array}$} & \multirow[b]{2}{*}{$\begin{array}{c}\text { Non anemic } \\
\mathrm{n}=88(\%)\end{array}$} & \multicolumn{3}{|c|}{ Anemia } & \multirow[b]{2}{*}{$\begin{array}{c}\text { Total anemicn }=227 \\
(\%)\end{array}$} \\
\hline & & & $\begin{array}{c}\text { Mild } \\
\mathrm{n}=93(\%)\end{array}$ & $\begin{array}{c}\text { Moderate } \\
\mathrm{n}=127(\%)\end{array}$ & $\begin{array}{c}\text { Severe } \mathrm{n}=07 \\
(\%)\end{array}$ & \\
\hline & \multicolumn{6}{|c|}{ Education status } \\
\hline Non-literate & $113(35.9)$ & $22(25.0)$ & $29(31.2)$ & $60(47.2)$ & $2(28.6)$ & $91(40.1)$ \\
\hline Can Sign & $3(1.0)$ & $1(1.1)$ & - & $2(1.6)$ & - & $2(0.9)$ \\
\hline Primary & $45(14.3)$ & $12(13.6)$ & $17(18.3)$ & $16(12.6)$ & - & $33(14.5)$ \\
\hline Secondary & $74(23.5)$ & $21(23.9)$ & $26(28.0)$ & $25(19.7)$ & $2(28.6)$ & $53(23.3)$ \\
\hline High Secondary & $39(12.4)$ & $15(17.0)$ & $8(08.6)$ & $13(10.2)$ & $3(42.9)$ & $24(10.6)$ \\
\hline Graduation & $32(10.2)$ & $12(13.6)$ & $13(14.0)$ & $7(5.5)$ & - & $20(8.8)$ \\
\hline \multirow[t]{2}{*}{ Post Graduate } & $9(2.9)$ & $5(5.7)$ & - & $4(3.1)$ & - & $4(1.8)$ \\
\hline & \multicolumn{6}{|c|}{ Monthly family income } \\
\hline$<5000$ & $234(74.3)$ & $55(62.5)$ & $70(75.3)$ & $103(81.1)$ & $6(85.7)$ & $179(78.9)$ \\
\hline 5000- 10000 & $57(18.1)$ & $23(26.1)$ & $15(16.1)$ & $18(14.2)$ & $1(14.3)$ & $34(15.0)$ \\
\hline \multirow[t]{2}{*}{$>10000$} & $24(7.6)$ & $10(11.4)$ & $8(8.6)$ & $6(4.7)$ & - & $14(6.1)$ \\
\hline & \multicolumn{6}{|l|}{ Marital status } \\
\hline Unmarried & $58(18.4)$ & $24(27.3)$ & $14(15.1)$ & $19(15.0)$ & $1(14.3)$ & $34(15.0)$ \\
\hline Married & $246(78.1)$ & $62(70.5)$ & $77(82.8)$ & $102(80.3)$ & $5(71.4)$ & $184(81.0)$ \\
\hline \multirow[t]{2}{*}{ Widow / Widower } & $11(3.5)$ & $2(2.2)$ & $2(2.1)$ & $6(4.7)$ & $1(14.3)$ & $9(4.0)$ \\
\hline & \multicolumn{6}{|c|}{ Sanitation facilities } \\
\hline Yes & $177(56.2)$ & $61(69.3)$ & $52(55.9)$ & $60(47.2)$ & $4(57.1)$ & $116(51.1)$ \\
\hline \multirow[t]{2}{*}{ No } & $138(43.8)$ & $27(30.7)$ & $41(44.1)$ & $67(52.8)$ & $3(42.9)$ & $111(48.9)$ \\
\hline & \multicolumn{6}{|c|}{ Socio economic status } \\
\hline Lower & $120(38.1)$ & $26(29.5)$ & $31(33.3)$ & $61(48.0)$ & $2(28.6)$ & $94(41.4)$ \\
\hline Upper lower & $164(52.0)$ & $47(53.4)$ & $52(55.9)$ & $60(47.3)$ & $5(71.4)$ & $117(51.5)$ \\
\hline Lower middle & $22(7.0)$ & $9(10.2)$ & $8(8.6)$ & $5(3.9)$ & - & $13(5.7)$ \\
\hline Upper middle & $9(2.9)$ & $6(6.8)$ & $2(2.2)$ & $1(0.8)$ & - & $3(1.3)$ \\
\hline
\end{tabular}


Table No: 4. Socio demographic profile wise mean hemoglobin level of study participants

\begin{tabular}{|c|c|c|c|c|c|c|c|c|}
\hline \multirow{2}{*}{$\begin{array}{l}\text { Socio demographic } \\
\text { parameters }\end{array}$} & \multicolumn{3}{|c|}{ Male } & \multicolumn{3}{|c|}{ Female } & \multirow[t]{2}{*}{ t value } & \multirow[t]{2}{*}{$\mathrm{p}$ value } \\
\hline & $\mathrm{n}$ & Mean & SD & $\mathrm{n}$ & Mean & SD & & \\
\hline \multicolumn{9}{|l|}{ Education status } \\
\hline Non-literate & 23 & 11.75 & 1.97 & 90 & 10.79 & 1.44 & $2.19 *$ & .037 \\
\hline Can Sign & 1 & 13.80 & - & 2 & 9.45 & 0.78 & $4.57^{\mathrm{NS}}$ & .137 \\
\hline Primary & 22 & 11.85 & 1.98 & 23 & 11.80 & 1.74 & $0.07^{\mathrm{NS}}$ & .941 \\
\hline Secondary & 43 & 12.41 & 1.91 & 31 & 10.77 & 1.40 & $4.28 * * *$ & .000 \\
\hline High Secondary & 23 & 12.83 & 2.42 & 16 & 10.30 & 1.71 & $3.81 * * *$ & .001 \\
\hline Graduation & 23 & 13.02 & 1.78 & 9 & 10.73 & 1.03 & $4.52 * * *$ & .000 \\
\hline Post Graduate & 6 & 12.02 & 2.13 & 3 & 11.87 & 0.92 & $0.15^{\mathrm{NS}}$ & .887 \\
\hline \multicolumn{4}{|c|}{$\mathrm{F}=1.32^{\mathrm{NS}}, \mathrm{df}=6, \mathrm{p}=.251$} & \multicolumn{5}{|c|}{$\mathrm{F}=2.54^{*}, \mathrm{df}=6, \mathrm{p}=.022$} \\
\hline \multicolumn{9}{|c|}{ Monthly family income } \\
\hline$<5000$ & 92 & 12.17 & 1.82 & 142 & 10.74 & 1.47 & $6.32 * * *$ & .000 \\
\hline $5000-10000$ & 35 & 12.49 & 2.21 & 22 & 11.61 & 1.70 & $1.70^{\mathrm{NS}}$ & .095 \\
\hline$>10000$ & 14 & 13.41 & 2.58 & 10 & 11.15 & 1.36 & $2.78^{*}$ & .011 \\
\hline \multicolumn{4}{|c|}{$\mathrm{F}=2.38^{\mathrm{NS}}, \mathrm{df}=2, \mathrm{p}=.096$} & \multicolumn{5}{|c|}{$\mathrm{F}=3.37^{*}, \mathrm{df}=2, \mathrm{p}=.037$} \\
\hline \multicolumn{9}{|l|}{ Marital status } \\
\hline Unmarried & 37 & 12.79 & 2.14 & 21 & 10.72 & 1.25 & $4.63 * * *$ & .000 \\
\hline Married & 103 & 12.22 & 1.98 & 143 & 10.92 & 1.56 & $5.52 * * *$ & .000 \\
\hline Widow / Widower & 1 & 13.30 & - & 10 & 10.50 & 1.42 & $1.88^{\mathrm{NS}}$ & .093 \\
\hline \multicolumn{4}{|c|}{$\mathrm{F}=1.19^{\mathrm{NS}}, \mathrm{df}=2, \mathrm{p}=.308$} & \multicolumn{5}{|c|}{$\mathrm{F}=0.48^{\mathrm{NS}}, \mathrm{df}=2, \mathrm{p}=.620$} \\
\hline \multicolumn{9}{|l|}{ Sanitation facilities } \\
\hline Yes & 87 & 12.70 & 2.18 & 90 & 11.09 & 1.55 & $5.65 * * *$ & .000 \\
\hline No & 54 & 11.85 & 1.64 & 84 & 10.64 & 1.46 & $4.41 * * *$ & .000 \\
\hline \multicolumn{4}{|c|}{$\mathrm{F}=6.03^{*}, \mathrm{df}=1, \mathrm{p}=.015$} & \multicolumn{5}{|c|}{$\mathrm{F}=3.83^{\mathrm{NS}}, \mathrm{df}=1, \mathrm{p}=.052$} \\
\hline \multicolumn{9}{|c|}{ Socio economic status } \\
\hline Lower & 26 & 12.01 & 1.85 & 94 & 10.84 & 1.49 & $2.96^{* *}$ & .005 \\
\hline Upper lower & 91 & 12.29 & 2.01 & 73 & 10.87 & 1.57 & $5.09^{* * *}$ & .000 \\
\hline Lower middle & 17 & 12.99 & 2.34 & 5 & 10.92 & 1.45 & $2.40^{*}$ & .035 \\
\hline Upper middle & 7 & 13.34 & 2.01 & 2 & 12.40 & - & $1.24^{\mathrm{NS}}$ & .262 \\
\hline Upper & - & - & - & - & - & - & - & - \\
\hline \multicolumn{4}{|c|}{$\mathrm{F}=1.40^{\mathrm{NS}}, \mathrm{df}=3, \mathrm{p}=.245$} & \multicolumn{5}{|c|}{$\mathrm{F}=0.69^{\mathrm{NS}}, \mathrm{df}=3, \mathrm{p}=.563$} \\
\hline
\end{tabular}

Level of significance $* * *=p<0.001, * *=p<0.01, *=p<0.05$, NS $=$ Not significant

Table No: 5. Association of gender with socio demographic factors and anemia

\begin{tabular}{|l|c|c|c|c|c|}
\hline \multicolumn{1}{|c|}{ Socio demographic parameters } & Male & Female & Chi square $\left(\chi^{2}\right)$ & $\mathrm{df}$ & $\mathrm{p}$ value \\
\hline Education & $141(44.76 \%)$ & $174(55.24 \%)$ & $47.47^{* * *}$ & 6 & .000 \\
\hline Monthly family income & $141(44.76 \%)$ & $174(55.24 \%)$ & $10.98^{* *}$ & 2 & .004 \\
\hline Marital status & $141(44.76 \%)$ & $174(55.24 \%)$ & $14.99^{* * *}$ & 2 & .001 \\
\hline Sanitation facilities & $141(44.76 \%)$ & $174(55.24 \%)$ & $3.15^{\mathrm{NS}}$ & 1 & .076 \\
\hline Socio economic status & $141(44.76 \%)$ & $174(55.24 \%)$ & $46.89^{* * *}$ & 3 & .000 \\
\hline Age category & $141(44.76 \%)$ & $174(55.24 \%)$ & $18.72^{* * *}$ & 3 & .000 \\
\hline Anemic prevalence & $141(44.76 \%)$ & $174(55.24 \%)$ & $34.16^{* * *}$ & 3 & .000 \\
\hline
\end{tabular}

Level of significance $* * *=p<0.001, * *=p<0.01, \mathrm{~N} . \mathrm{S}=$ Not significant 
Table No: 6. Association of anemia with socio demographic factors

\begin{tabular}{|c|c|c|c|c|c|}
\hline \multirow{2}{*}{$\begin{array}{c}\text { Socio demographic } \\
\text { parameters }\end{array}$} & \multicolumn{2}{|c|}{ Sex combined } & \multirow{2}{*}{$\begin{array}{l}\text { Chi square } \\
\qquad\left(\chi^{2}\right)\end{array}$} & \multirow[t]{2}{*}{ df } & \multirow[t]{2}{*}{$\mathrm{p}$ value } \\
\hline & Non anemic & Anemic & & & \\
\hline Education & $88(27.9 \%)$ & $227(72.1 \%)$ & $11.12^{\mathrm{NS}}$ & 6 & .085 \\
\hline Monthly family income & $88(27.9 \%)$ & $227(72.1 \%)$ & $8.89 *$ & 2 & .012 \\
\hline Marital status & $88(27.9 \%)$ & $227(72.1 \%)$ & $6.63 *$ & 2 & .036 \\
\hline Sanitation facilities & $88(27.9 \%)$ & $227(72.1 \%)$ & $8.55 * *$ & 1 & .003 \\
\hline Socio economic status & $88(27.9 \%)$ & $227(72.1 \%)$ & $10.93 *$ & 3 & .012 \\
\hline Age category & $88(27.9 \%)$ & $227(72.1 \%)$ & $5.90^{\mathrm{NS}}$ & 3 & .116 \\
\hline Gender & $88(27.9 \%)$ & $227(72.1 \%)$ & $13.61 * * *$ & 1 & .000 \\
\hline
\end{tabular}

Level of significance $* * *=p<0.001, * *=p<0.01, *=p<0.05$, N. S $=$ Not significant

Table No: 7. Pearson's Correlation coefficient (r) between hemoglobin level and anemic status with socio demographic variables among Barwar people

\begin{tabular}{|l|c|c|c|c|}
\hline \multirow{2}{*}{$\begin{array}{l}\text { Socio demographic } \\
\text { parameters }\end{array}$} & \multicolumn{2}{|c|}{ Hemoglobin level } & \multicolumn{2}{c|}{ category wise Anemic status } \\
\cline { 2 - 5 } & $\mathrm{r}$ value & $\mathrm{p}$ value & $\mathrm{r}$ value & $\mathrm{p}$ value \\
\hline Age category & $-.116^{*}$ & $(.039)$ & $-.124^{*}$ & .028 \\
\hline Gender & $-.391^{* *}$ & $(.000)$ & $-.294^{* *}$ & .000 \\
\hline Education & $.226^{* *}$ & $(.000)$ & $.191^{* *}$ & .001 \\
\hline Monthly family income & $.214^{* *}$ & $(.000)$ & $.172^{* *}$ & .002 \\
\hline Marital status & $-.140^{*}$ & $(.013)$ & $-.140^{*}$ & .013 \\
\hline Sanitation facilities & $-.199^{*}$ & $(.000)$ & $-.169^{* *}$ & .003 \\
\hline Socio economic status & $.245^{* *}$ & $(.000)$ & $.206^{* *}$ & .000 \\
\hline
\end{tabular}

$*$ = Correlation is significant at the 0.05 level (2-tailed).

$* *=$ Correlation is significant at the 0.01 level (2-tailed).

\section{Discussion}

This study revealed that the overall prevalence of anemia as $72.1 \%$ among the Barwar people of Gonda district, Uttar Pradesh. It was higher in females $(80.5 \%)$ than males $(61.7 \%)$. Another study found in Lucknow, $54.8 \%$ patients attending OPD's were found to be anaemic. It was higher in females $(65 \%)$ than males $(41.2 \%) .{ }^{8}$ Similar study found in Lucknow, Uttar Pradesh the overall prevalence of anemia was $56.3 \%$ in school going adolescent girl in the Lucknow district. ${ }^{7}$ So this study show the prevalence of anemia is also high than the others study of Uttar Pradesh. These differences in the prevalence of anemia may be due to difference in the study area, different community/ people, different age groups and others associated factors. The present study clearly indicated that the overall prevalence of anemiawas $72.1 \%$, a severe public health problem as per WHO classification (WHO, 2001). ${ }^{4}$
Association of low socio-economic status, low education and BMI was associated with high prevalence of anaemia in a study done in rural population of North India. $^{8,23}$ An inverse relationship was observed between prevalence of anemia and socioeconomic status in this study. The similar finding was reported by other studies. ${ }^{\text {7, 15-19 }}$

As per World Health Organization anaemia particularly iron deficiency anaemia "reduces the work capacity of individuals and entire populations, bringing serious economic consequences and obstacles to national development", 20 Singh et al, in their study concluded that high prevalence of anaemia among females of Uttar Pradesh is a burden both at personal and familial level. It is bound to have negative impact on economic and social productivity. Further they observed that diet may play a role in females (belonging to overweight 
and high-income category) suffering from moderate to severe anaemia. ${ }^{21}$ High prevalence of anaemia in females may reflect social and biological vulnerability both within society and the household. ${ }^{22}$

These studies find out the significant correlation between all socio demographic parameters and hemoglobin and anemia. Previous reports have shown that there is definite correlation between socioeconomic status (SES) and anemia. ${ }^{4,6}$

\section{Conclusion}

Anaemia is more common in females than males. Anemia is known to be associated with multiple factors, such as poor socioeconomic status, low education, poor diet both in quantity and quality, lack of health and nutrition awareness, and a high rate of infectious diseases. Health education plays a vital role in increasing knowledge of the people. The main recommendations of the study included implementing more efforts to improve the quality of health services, improve the awareness about anaemia, improve family planning and birth spacing program to diminish maternal iron losses, intensify measures to improve public awareness and implement an advocacy program to increase utilization of health services.

\section{Acknowledgements}

All subjects who participated in the study are gratefully acknowledged. Authors are thankful to the advisory committee and Director of the Anthropological Survey of India, Head Office, Kolkata, for providing necessary financial support, infrastructural and instrumental facilities for carrying out this study. Also thankful to Arup Roy and Anup Giri for their help and cooperation in carrying out this study.

\section{Financial Support Sponsorship}

This study is funded by Anthropological Survey of India under the Ministry of Culture and project entitled "Anthropological study among Denotified, Nomadic and Semi-Nomadic Communities" and "General Health, Hygiene and
Nutritional

Anthropometric

study among

Denotified, Nomadic and Semi-Nomadic Communities".

\section{Conflict of Interest}

The author declares that there is no conflict of interest regarding the publication of this paper.

\section{References}

1. Yip R. Iron fortification: prevention of iron deficiency for developing countries. Paper presented at: Institute of Food Technologists Annual Meeting; June 20-24, 1988; Atlanta, GA.

2. van den Broek NR, Letsky EA. Etiology of anaemia in pregnancy in south Malawi. Am J Clin Nutr 2000;72:247S-256S.

3. International Institute for Population Sciences (IIPS) and Macro International 2017. National Family Health Survey (NFHS-4), 2015-16: Uttar Pradesh. Mumbai: IIPS.

4. World Health Organization. Iron Deficiency Anaemia: Assessment, Prevention and Control. A guide for programme managers. WHO: Geneva, 2001.

5. McLean E, Cogswell M, Egli I, Wojdyla D. de Benoist B. Worldwide prevalence of anaemia, WHO Vitamin and Mineral Nutrition Information System, 1993-2005. Public Health Nutr 2009; 12: 444-454.

6. Gompakis N, Economou M, Tsantali C, Kouloulias V, Keramida M, AthanasiouMetaxa M. The effect of dietary habits and socioeconomic status on the prevalence of iron deficiency in children of northern Greece. Acta Haematol 2007; 117: 200-204.

7. Sachan B, Idris MZ, Singh A. Effect of sociodemographic characteristics on the prevalence of anemia among school going adolescent girls in Lucknow district, India. South East Asia J Public Health 2013;2(1):8-12.

8. Rastogi S, Waseem S. M.A, Bano R. Study of anaemia amongst OPD patients visiting a private medical college in Lucknow, Uttar 
Pradesh. Indian J Clin Anat Physiol 2018;5(4):546-552.

9. Kim JY, Shin S, Han K, Lee KC, Kim JH, Choi YS, Kim DH, Nam GE, Yeo HD, Lee HG and Ko BJ. Relationship between socioeconomic status and anaemia prevalence in adolescent girls based on the fourth and fifth Korea National Health and Nutrition Examination Surveys. Eur J Clin Nutr 2014; 68(2):253-8. doi: 10.1038/ejcn.2013.241.

10. Dey S, Goswami S and Goswami M. Prevalence of anaemia in women of reproductive age in Meghalaya: Alogistic regression analysis. Turk J Med Sci 2010;40(5):783-789.

11. Pratima V, Shraddha S, Ashutosh K, Archna $G$ and Ahilesh K. Prevalence of Anaemia in adults with respectto Socio-Demographic status, Blood groups and religionin North Indian population. Int $\mathrm{J}$ Biol Med Res2012;3(4):2441-2447.

12. World Health Organization. Hemoglobin concentrations for the diagnosis of Anaemia and assessment of severity. Vitamin and Mineral Nutrition Information System. Geneva, World Health Organization, 2011 (WHO/NMH/NHD/MNM/11.1)http://www.w ho.int/vmnis/indicators/haemoglobin.pdf.

13. Singh T, Sharma S, Nagesh S. Socioeconomic status scales updated for 2017. Int J Res Med Sci 2017;5:3264-7.

14. Census of India, Ministry of Home Affairs, Government of India, Office of the Registrar General and Census Commissioner, India, Controller of Publication, New Delhi. 2011.

15. Pathak P, Kapil U, Kapoor SK, Saxena R, Kumar A, Gupta N, et al. Prevalence of multiple micronutrient deficiencies amongst pregnant women in a rural area of Haryana. Indian J Pediatr 2004;71(11):1007-14.

16. Basu S, Basu S, Hazarika R, Parmar V. Prevalence of anemia among school going adolescents of Chandigarh. Indian Pediatr 2005;42(6):593-7.
17. Rawat CM, Garg SK, Singh JV, Bhatnagar M. Socio-demographic correlates of anaemia among adolescent girls in rural areas of the district Meerut, Uttar Pradesh. Indian J Community Med 2001;26(4):173-5.

18. Kapoor G, Aneja S. Nutritional disorders in adolescent girls. Indian Pediatr 1992;29 (8):969-73.

19. Arya AK, Lal P, Kumar N, Barman S. Prevalence of anemia among adolescent girls in an urban slum of Kanpur, Uttar Pradesh. Int J Med Sci Public Health 2017;6(9):13781381.

20. Yadavar S. Anaemia Is the Biggest Cause of Disability In India, Worst In BRICS. 2016. https://www.health-check.in/anaemia-is-thebiggest-cause-of-disability-in-india-worst-inbrics-43371/

21. Singh BP, Maheshwari S and Gupta PK. Anaemia in Married Females of Uttar Pradesh and Its relation to Body Mass Index: Application of Poisson Regression. Journal of Data Sciences2017;15:267-274.

22. Maiti S, Ali KM, Ghosh A, Ghosh K, Ghosh D and PaulS. Prevalence of Anaemia among Rural Women Population of Paschim Medinipur, West Bengal, India. Nepal Journal of Medical Sciences2013;2(1):9-12.

23. Malhotra P, Kumari S, Kumar R and Varma S.Prevalence of anaemia in adult rural population of north India. J Assoc Physicians India 2004;52:18-20.

24. de Benoist B, McLean E, Egli I, Well MC, editors. Worldwide prevalence of anemia 1993-2005, WHO global database on anemia. Geneva: WHO; 2008; 1-40.

25. International Institute for Population Sciences (IIPS) and Macro International 2017. National Family Health Survey (NFHS-4), 2015-16: India. Mumbai: IIPS. 